\title{
Effect of Electroplating Waste Water on Immune Function in Kunming Mice
}

\author{
Zongqi Ma1*, Guirong Wang1*, Yufen Tian²*, Deli Xu1", Xiaofeng Miao1, Ying Zhang1, \\ Jiao Meng1, Hong Ni'1, Weiwei Sun ${ }^{1}$ \\ ${ }^{1}$ College of Life Sciences, Qufu Normal University, Qufu, China \\ ${ }^{2}$ Library, Qufu Normal University, Qufu, China \\ Email: "xudl1975@163.com
}

Received 19 May 2016; accepted 9 July 2016; published 12 July 2016

Copyright (C) 2016 by authors and Scientific Research Publishing Inc.

This work is licensed under the Creative Commons Attribution International License (CC BY). http://creativecommons.org/licenses/by/4.0/

cc) (i) Open Access

\begin{abstract}
Electroplating waste water is considered to be harmful to health of animals. In the present study, we tested the hypothesis that electroplating waste water would suppress immune functions in Kunming mice. Twenty-six mice were randomly divided into the control group $(n=13)$ and the experimental group $(n=13)$, in which the latter drank electroplating waste water. We found that body mass and most organ wet masses (heart, lungs, liver, kidneys, stomach, caecum, colon, testes, epididymis, seminal vesicals) were not influenced by electroplating waste water. However, stomach with its content, small intestine, small intestine with its contents and colon with its contents were higher in the experimental group than in the control group. As expected, phytohaemagglutinin (PHA) response indicative of cellular immunity was suppressed by electroplating waste water. White blood cells, thymus and spleen mass were all not response to electroplating waste water. Taken together, electroplating waste water had different effects on distinct components of immune system in Kunming mice.
\end{abstract}

\section{Keywords}

Electroplating Waste Water, Mice, Phytohaemagglutinin (PHA) Response, Immune Function

\section{Introduction}

Electroplating waste water is produced in the electroplating industries such as the machinery manufactured, light and electronic industries. Due to its harmful components such as chromium, cadmium and cyanide and other

${ }^{*}$ Co-first authors.

"Corresponding author.

How to cite this paper: Ma, Z.Q., Wang, G.R., Tian, Y.F., Xu, D.L., Miao, X.F., Zhang, Y., Meng, J., Ni, H. and Sun, W.W. (2016) Effect of Electroplating Waste Water on Immune Function in Kunming Mice. Natural Science, 8, 315-320. 
toxic chemicals, it is considered to pollute the environments and impair human health [1] [2].

Some researchers have reported the harmful effects of electroplating waste water in shrimps and fishes. For example, electroplating waste water has harmful influence on the embryos and juveniles of shrimps and fishes [3]-[6]. Many fishes died in a river near the city of Guanzhou in China in February 2006, which was mainly caused by electroplating waste water [7]. However, influence of electroplating waste water on small mammals receives little attention.

Phytohaemagglutinin (PHA) response has been used to evaluate mammalian cellular immunity [8] [9]. Immune organs such as thymus and spleen are also indicative of immune function [10]-[12]. Thymus is crucial for primary T cell development [10], and a larger spleen implies a stronger immune system [12]. In addition, total white blood cells (WBC), which are important for immune response against pathogens, are also useful to assess the overall health [11]. Due to the scarce research about the effect of electroplating waste water on rodents, we tested the hypothesis that electroplating waste water would suppress immune function in mice in the present study.

\section{Materials and Methods}

\subsection{Animals and Experimental Design}

All animal procedures were licensed under the Institutional Animal Care and Use Committee of Qufu Normal University. Adult male Kunming mice (age: 5 - 6 months) used in this study were obtained from Experiment Animal Center in Shandong Lukang Pharmaceutical Co., Ltd. The animals were housed individually in plastic cages $(30 \mathrm{~cm} \times 15 \mathrm{~cm} \times 20 \mathrm{~cm}$ ) with sawdust as bedding under a natural light. The experiment was carried out from May $10^{\text {th }}$ to June $15^{\text {th }}$ in 2014. Standard rat pellets chow (Shandong Lukang Pharmaceutical Co., Ltd., Jining, China) and water were provided ad libitum. After body mass stabilized, 26 male mice were randomly divided into the control group $(n=13)$ and the experimental group $(n=13)$. Mice in the control group had free access to water, whereas mice in the experimental group had free access to the electroplating waste water (chromium (Cr): $0.0784 \mu \mathrm{g} / \mathrm{ml}$, nickel (Ni): $36.4 \mu \mathrm{g} / \mathrm{ml}$, lead (Pb): $277 \mu \mathrm{g} / \mathrm{ml}$, Copper (Cu): $153.2 \mu \mathrm{g} / \mathrm{ml}, \mathrm{Zinc}$ (Zn): $12.6 \mu \mathrm{g} / \mathrm{ml}$ ). Food was provided ad libitum throughout the experiment and the experimental course lasted for 27 days. One mouse in the control group and another in the experimental group died after 8 days and 22 days respectively. These two mice were not included in the subsequent statistical analysis. Day 0 and day $\mathrm{n}$ represented initial day and n days of treatment, respectively.

\subsection{Organs and Body Composition}

Organs were examined as described previously [13]. In brief, after mice were killed, the visceral organs, including heart, thymus, lungs, liver, spleen, kidneys, adrenal glands, testes, epididymis, seminal vesicals and the digestive organs with contents (i.e., stomach, small intestine, caecum and colon) were dissected and weighed ( \pm 1 $\mathrm{mg}$ ). The stomach, small intestine, caecum and colon were rinsed with saline to eliminate all the gut contents, before being weighed.

\subsection{Cellular Immunity Assays}

PHA response was assessed as described previously [13]. Specifically, Kunming mice in the control and experimental groups on day 24 were caught, then we measured their footpad thickness of the left hind foot with a micrometer (Digimatic Indicator ID-C Mitutoyo Absolute cod. 547-301, Japan) to $\pm 0.01 \mathrm{~mm}$. Immediately thereafter, mice in the control and experimental groups were injected subcutaneously 0.1 mg of PHA (PHA-P, Sigma L-8754) dissolved in $0.03 \mathrm{~mL}$ of sterile saline ( $\mathrm{pH} 7.4$ ) in the middle of the footpad. After 6 h, $12 \mathrm{~h}, 24 \mathrm{~h}$, $48 \mathrm{~h}$ and $72 \mathrm{~h}$ injection, we measured footpad thickness. The PHA response (i.e., cellular immunity) was calculated as the difference between pre- and post-injection measurements divided by initial footpad thickness (PHA response $=($ post PHA - pre PHA)/pre PHA). Six measures of footpad thickness were taken to obtain the value of each mouse [13].

\subsection{White Blood Cells Assays}

White blood cells were counted as described previously [13]. Briefly, at the end of the experiment, $20 \mu \mathrm{L}$ whole blood was diluted immediately in $0.38 \mathrm{~mL}$ solution containing 1.5\% glacial acetic acid, 1\% crystal violet (Sigma) 
and the leukocytes were counted in an improved Neubauer chamber using microscope. The total number of WBC was determined by counting all leucocytes in the four corner large-squares of the Neubauer chamber, and multiplying the raw data by $5 \times 10^{7}$ to obtain the final values $\left(10^{9}\right.$ cells/L).

\subsection{Statistical Analysis}

Data were analyzed using SPSS 13.0 software (SPSS Inc., Chicago, IL, USA). Prior to all statistical analyses, data were examined for normality and homogeneity of variance, using Kolmogorov-Smirnov and Levene tests, respectively. The ratio values including PHA response were subjected to arcsine transformation. The differences of body mass between the control and experimental groups at any time point were analyzed by independentsamples t-test. Group differences in wet organ mass with body mass as the covariate were analyzed by General Linear Model multivariate analysis followed by Bonferroni post hoc tests. Group differences in other parameters (body compositions, PHA response, WBC) were analyzed by independent-samples t-test. Results were expressed as mean $\pm \mathrm{SE}$, and $P<0.05$ was considered to be statistically significant.

\section{Results}

\subsection{Body Mass}

Body mass did not differ between the control and experiment groups from the beginning to the end of the experiment (day 0: $\mathrm{t}=-0.592, \mathrm{df}=21, P=0.560$; day 27: $\mathrm{t}=0.829$, $\mathrm{df}=21, P=0.417$ ) (Figure 1 ).

\subsection{Organs}

Electroplating waste water increased the masses of stomach with its content, small intestine, small intestine with its contents and colon with its contents (Table 1). However, masses of immune organs (i.e., thymus and spleen) and other organs were not influenced by electroplating waste water (Table 1).

\subsection{Cellular Immunity}

Electroplating waste water suppressed $6 \mathrm{~h}(\mathrm{t}=2.781, \mathrm{df}=21, P=0.011)$ and $12 \mathrm{~h}(\mathrm{t}=2.185, \mathrm{df}=21, P=0.040)$ of PHA responses (Figure 2). PHA responses of $24 \mathrm{~h}(\mathrm{t}=1.547, \mathrm{df}=21, P=0.137), 48 \mathrm{~h}(\mathrm{t}=1.787, \mathrm{df}=21$, $P=0.088), 72 \mathrm{~h}(\mathrm{t}=1.303, \mathrm{df}=21, P=0.207)$ did not differ between the experimental and control groups.

\subsection{White Blood Cells}

WBC in the experiment group was not different from the control group $(\mathrm{t}=0.140, \mathrm{df}=21, P=0.890$ ) (Figure 3).

\section{Discussion}

As expected, cellular immunity in Kunming mice was impaired by electroplating waste water, however other

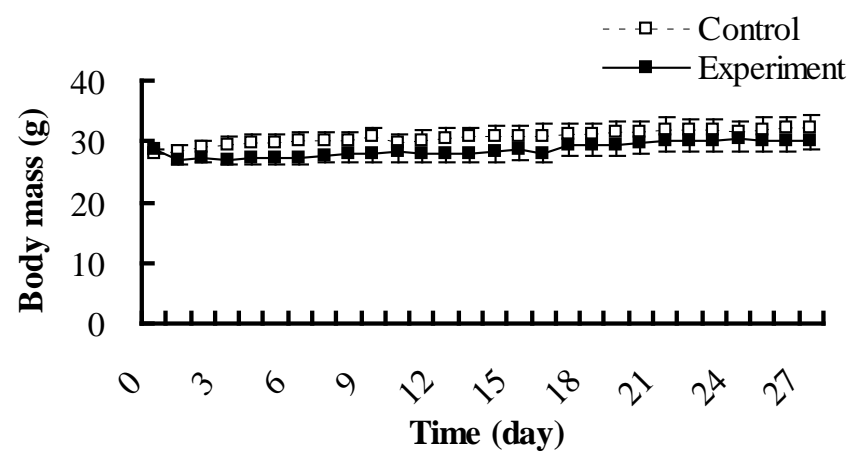

Figure 1. Effect of electroplating waste water on body mass in Kunming mice. 


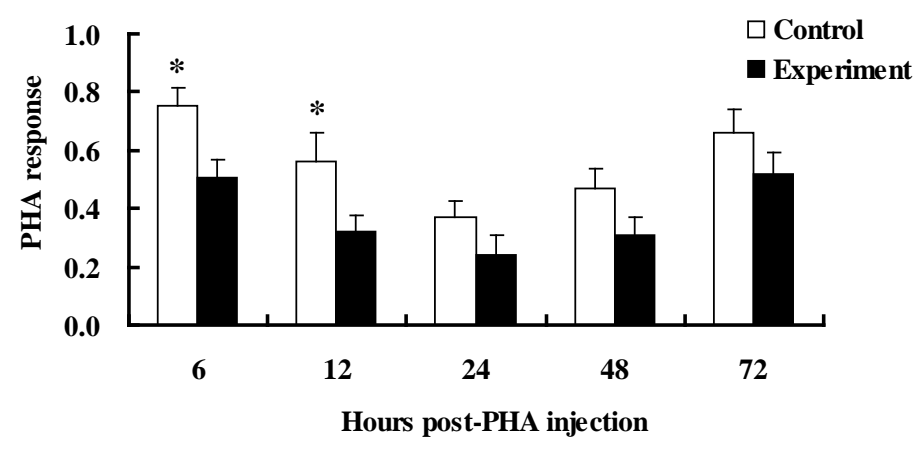

Figure 2. Effect of electroplating waste water on PHA response in Kunming mice. An asterisk ( $\left(^{*}\right)$ indicates statistical differences at $P<$ 0.05 .

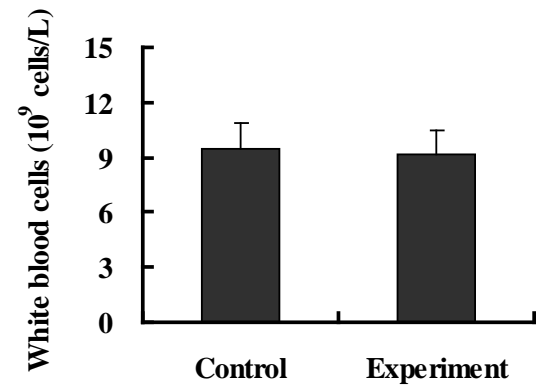

Figure 3. Effect of electroplating waste water on total white blood cells in Kunming mice.

immunological parameters including white blood cells, thymus and spleen mass did not differ between the control and experimental mice.

\subsection{Body Mass, Organs and Waste Water}

Electroplating waste water had no effect on body mass and most organ masses. Stomach with its content, small intestine, small intestine with its contents and colon with its contents increased upon electroplating waste water, implying that the digestive capacity of mice might improve.

\subsection{Immunity and Waste Water}

Cellular immunity in mice was impaired by electroplating waste water, indicating their capacity of fighting against pathogens decreased. Other immunological parameters including white blood cells, thymus and spleen mass were all not response to electroplating waste water. These results demonstrated that different components of immune system had distinct sensitivities to electroplating waste water. Due to the complex components of electroplating waste water in our study, it was difficult to clarify which component played the major role in affecting immune function in mice. Effect of single heavy metal on immunity has been conducted in some researches. For example, dietary chromium can increase the levels of immunoglobulin $\mathrm{M}$ in juvenile rockfish [14]. Lower dietary nickel concentrations suppressed while higher nickel concentrations increased immune responses of Fabricius larvae [15]. In addition, negative correlation was observed between elevated lead levels and the percentage of natural killer cells, blood hepatitis B surface antibody levels in children from an electronic waste recycling area [16] [17]. Although copper is recognized as an essential trace element, uncertainties remain regarding copper reference values for humans. For instance, very low copper intake may impair immune function in human [18]. However, low levels of copper contamination may enhance immunity of estuarine bivalves [19]. Zinc is an essential trace element which is important for maintenance and development of immune cells of both the innate and adaptive immune system [20]. Synergistic or antagonistic actions among different metals in electroplating waste water on immunity in mice need further researches in the future. 
Table 1. Effect of electroplating waste water on wet organ mass in Kunming mice.

\begin{tabular}{|c|c|c|c|}
\hline Parameters & Control & Experiment & Statistical summary \\
\hline Sample size & 12 & 12 & \\
\hline Heart (g) & $0.153 \pm 0.005$ & $0.151 \pm 0.005$ & 0.715 \\
\hline Lungs (g) & $0.342 \pm 0.033$ & $0.322 \pm 0.033$ & 0.671 \\
\hline Liver (g) & $1.777 \pm 0.049$ & $1.750 \pm 0.049$ & 0.703 \\
\hline Spleen (g) & $0.113 \pm 0.009$ & $0.089 \pm 0.009$ & 0.085 \\
\hline Kidneys (g) & $0.459 \pm 0.019$ & $0.473 \pm 0.019$ & 0.614 \\
\hline Stomach with contents (g) & $0.655 \pm 0.069^{\mathrm{b}}$ & $0.976 \pm 0.069^{\mathrm{a}}$ & 0.004 \\
\hline Stomach (g) & $0.189 \pm 0.008$ & $0.202 \pm 0.008$ & 0.232 \\
\hline Small intestine with contents (g) & $1.828 \pm 0.075^{\mathrm{b}}$ & $2.070 \pm 0.075^{\mathrm{a}}$ & 0.034 \\
\hline Small intestine (g) & $0.880 \pm 0.051^{\mathrm{b}}$ & $1.078 \pm 0.051^{\mathrm{a}}$ & 0.012 \\
\hline Small intestine length $(\mathrm{cm})$ & $56.5 \pm 1.3$ & $58.5 \pm 1.3$ & 0.287 \\
\hline Caecum with contents (g) & $0.493 \pm 0.040$ & $0.575 \pm 0.040$ & 0.169 \\
\hline Caecum (g) & $0.225 \pm 0.052$ & $0.122 \pm 0.052$ & 0.173 \\
\hline Caecum length $(\mathrm{cm})$ & $2.530 \pm 0.099$ & $2.795 \pm 0.099$ & 0.073 \\
\hline Colon with contents (g) & $0.555 \pm 0.039^{\mathrm{b}}$ & $0.689 \pm 0.039^{\mathrm{a}}$ & 0.024 \\
\hline Colon (g) & $0.298 \pm 0.025$ & $0.283 \pm 0.025$ & 0.676 \\
\hline Colon length $(\mathrm{cm})$ & $10.572 \pm 1.235$ & $74.262 \pm 5.623$ & 0.360 \\
\hline Total digestive tract (g) & $1.403 \pm 0.089$ & $1.483 \pm 0.089$ & 0.534 \\
\hline Total digestive tract length $(\mathrm{cm})$ & $69.6 \pm 4.7$ & $135.6 \pm 4.9$ & 0.339 \\
\hline Epedidymus (g) & $0.072 \pm 0.007$ & $0.066 \pm 0.007$ & 0.548 \\
\hline Testes (g) & $0.271 \pm 0.018$ & $0.239 \pm 0.018$ & 0.222 \\
\hline Seminal vesical (g) & $0.166 \pm 0.013$ & $0.152 \pm 0.013$ & 0.437 \\
\hline
\end{tabular}

Values are means \pm SE. Values for a specific parameter that share different superscripts are significantly different at $P<0.05$, determined by General Linear Model multivariate analysis followed by Bonferroni post hoc tests with body mass as the covariate ns, not significant.

\section{Conclusion}

In summary, electroplating waste water harmed cellular immunity in mice, whereas other immunological parameters (i.e., white blood cells, thymus and spleen mass) were not response to electroplating waste water. Due to the complex constituents of electroplating waste water, further research is required to study synergistic or antagonistic actions among different metals of electroplating waste water on immune function in the future. Taken together, electroplating waste water had distinct impacts on different immunological parameters.

\section{Acknowledgements}

The present study was supported by grants from the National Natural Science Foundation of China (No. 31370427), Natural Science Foundation of Shandong province (ZR2013CM019) and Undergraduate Scientific Research and Training Program of Qufu Normal University (2014A054) and the Crosswise Project (hxkj2014001).

\section{References}

[1] Cai, Y. (2010) Effect of Electroplating Wastewater on Human Health and Its Centralized Processing. Agricultural Journal of Environmental Science, 29, 205-208.

[2] Gao, C., Liu, Z. and Zhou, P. (2013) Electroplating Industry Environment Analysis and Pollution Control Counter- 
measures. Environmental Protection, 5, 206-207.

[3] Ma, S. and Qu, K. (2004) Acute Toxicity Effect of Three Kinds of Industrial Wastewater on Chinese Shrimp Larva and Postlarva. Chinese Fisheries Science, 3, 220-225.

[4] Qu, K., Chen, M., Ma, S. and Xin, F. (2003) Toxicity Effect of Three Kinds of Industrial Wastewater on Flounder Embryos. Chinese Fisheries Science, 2, 155-160.

[5] Qu, K., Chen, M., Ma, S. and Xin, F. (2002) Acute Toxic Effect and Joint Toxicity of Several Kinds of Industrial Wastewater on Flounder Larvaes. Marine Fisheries Research, 23, 40-46.

[6] Qu, K., Ma, S., Qi, M., Bu, X., Qiao, X. and Yuan, J. (2004) Toxic Effects of Three Kinds of Industrial Waste Water on Chinese Prawn Embryo. Marine Fisheries Research, 25, 29-35.

[7] Zhu, D., Hu, D., Yu, W. and Liang, Y. (2008) The Application of Acute Toxic Test in Fish on the Dead Fish Events Arbitration Monitoring. Environment and Ecology in the Three Gorges, 1, 19-22.

[8] Smits, J.E., Bortolotti, G.R. and Tella, J.L. (1999) Simplifying the Phytohaemagglutinin Skin-Testing Technique in Studies of Avian Immunocompetence. Functional Ecology, 13, 567-572. http://dx.doi.org/10.1046/j.1365-2435.1999.00338.x

[9] Bellocq, J.G., Krasnov, B.R., Khokhlova, I.S. and Pinshow, B. (2006) Temporal Dynamics of a T-Cell Mediated Immune Response in Desert Rodents. Comparative and Biochemical Physiology Part A, 145, 554-559. http://dx.doi.org/10.1016/j.cbpa.2006.08.045

[10] Savino, W. and Dardenne, M. (2000) Neuroendocrine Control of Thymus Physiology. Endocrine Reviews, 21, 412443. http://dx.doi.org/10.1210/er.21.4.412

[11] Calder, P.C. and Kew, S. (2002) The Immune System: A Target for Functional Foods? British Journal of Nutrition, 88, S165-S176. http://dx.doi.org/10.1079/BJN2002682

[12] Smith, K.G. and Hunt, J.L. (2004) On the Use of Spleen Mass as a Measure of Avian Immune System Strength. Oecologia, 138, 28-31. http://dx.doi.org/10.1007/s00442-003-1409-y

[13] Xu, D.L. and Wang, D.H. (2010) Fasting Suppresses T Cell-Mediated Immunity in Female Mongolian Gerbils (Meriones unguiculatus). Comparative and Biochemical Physiology Part A, 155, 25-33. http://dx.doi.org/10.1016/j.cbpa.2009.09.003

[14] Kim, J.H. and Kang, J.C. (2016) The Toxic Effects on the Stress and Immune Responses in Juvenile Rockfish, Sebastes schlegelii Exposed to Hexavalent Chromium. Environmental Toxicology and Pharmacology, 43, 128-133. http://dx.doi.org/10.1016/j.etap.2016.03.008

[15] Sun, H.X., Dang, Z., Xia, Q., Tang, W.C. and Zhang, G.R. (2011) The Effect of Dietary Nickel on the Immune Responses of Spodoptera litura Fabricius Larvae. Journal of Insect Physiology, 57, 954-961. http://dx.doi.org/10.1016/j.jinsphys.2011.04.008

[16] Xu, X., Chen, X., Zhang, J., Guo, P., Fu, T., Dai, Y., Lin, S.L. and Huo, X. (2015) Decreased Blood Hepatitis B Surface Antibody Levels Linked to E-Waste Lead Exposure in Preschool Children. Journal of Hazardous Materials, 298, 122-128. http://dx.doi.org/10.1016/j.jhazmat.2015.05.020

[17] Zhang, Y., Huo, X., Cao, J., Yang, T., Xu, L. and Xu, X. (2016) Elevated Lead Levels and Adverse Effects on Natural Killer Cells in Children from an Electronic Waste Recycling Area. Environmental Pollution, 213, 143-150. http://dx.doi.org/10.1016/j.envpol.2016.02.004

[18] Bost, M., Houdart, S., Oberli, M., Kalonji, E., Huneau, J. and Margaritis, I. (2016) Dietary Copper and Human Health: Current Evidence and Unresolved Issues. Journal of Trace Elements in Medicine and Biology, 35, 107-115. http://dx.doi.org/10.1016/j.jtemb.2016.02.006

[19] Ivanina, A.V., Hawkins, C. and Sokolova, I.M. (2016) Interactive Effects of Copper Exposure and Environmental Hypercapnia on Immune Functions of Marine Bivalves Crassostrea virginica and Mercenaria mercenaria. Fish \& Shellfish Immunology, 49, 54-65. http://dx.doi.org/10.1016/j.fsi.2015.12.011

[20] Bonaventura, P., Benedetti, G., Albarède, F. and Miossec, P. (2015) Zinc and Its Role in Immunity and Inflammation. Autoimmunity Reviews, 14, 277-285. http://dx.doi.org/10.1016/j.autrev.2014.11.008 
Submit or recommend next manuscript to SCIRP and we will provide best service for you:

Accepting pre-submission inquiries through Email, Facebook, LinkedIn, Twitter, etc.

A wide selection of journals (inclusive of 9 subjects, more than 200 journals)

Providing 24-hour high-quality service

User-friendly online submission system

Fair and swift peer-review system

Efficient typesetting and proofreading procedure

Display of the result of downloads and visits, as well as the number of cited articles

Maximum dissemination of your research work

Submit your manuscript at: http://papersubmission.scirp.org/ 